\title{
Aktuální otázky protidestičkové léčby
}

Problematice současné doporučené protidestičkové léčby a její úhradě a souvislosti kardiovaskulárních onemocnění s erektilní dysfunkcí se ve svých přednáškách na XXII. výročním sjezdu České kardiologické společnosti v květnu 2014 v Brně věnovali prof. PhDr. Petr Weiss, Ph.D., DSc. (Sexuologický ústav, 1. LF UK a VFN), doc. MUDr. Zuzana Motovská, Ph.D. (III. interní klinika, 3. LF UK a FNKV, Praha) a MUDr. Roman Miklík, Ph.D. (Interní kardiologická klinika, FN Brno).

Erektilní dysfunkce je často opomíjená zejména u pacientů s kardiovaskulárním onemocněním

Jak prípomnèl prof. Weiss, erektilní dysfunkce (ED) a kardiovaskulární choroby spolu úzce souvisejí. Zhruba polovina mužư s kardiovaskulárním onemocněním má také $E D$, přesto je tento stav $v$ ČR léčen jen asi u $8 \%$ z nich. Svưj podíl na tom mají $i$ lékaří, $z$ nichž pouze pětina po tomto onemocnění u svých pacientů pátrá.

Rizikové faktory i komorbidity kardiovaskulárních onemocnění a erektilní dysfunkce jsou shodné: věk, kouření, hypertenze, diabetes, dyslipidemie, deprese, obezita, sedavý způsob života. Zjištěna byla také významná souvislost těchto onemocnění: 38-42 \% mužů S ED má hypertenzi a 52-68 \% mužủ s hypertenzí trpí ED. Erektilní dysfunkce postihuje $49 \%$ mužů s koronárním onemocněním, 42 \% mužů s ED má dyslipidemii a 20 \% z nich má diabetes.

Podle českého výzkumu z roku 2001 zahrnujícího 2542 mužů trpí ED 54,1 \% ve věku 35-65 let, přičemž skoro polovina z nich má středně těžkou nebo těžkou ED, mezi nejčastější zdravotní problémy mužů s ED patří urologické obtíže, diabetes mellitus a infarkt myokardu, zatímco psychické obtíže uvádějí muži nejméně často. Podíl pacientů se středně těžkou a těžkou ED v ordinacích internistů a kardiologů činí 55-56 \%, přičemž u diabetologů je to dokonce $62 \%$ a u urologů $63 \%$ (obr. 1). Průzkum také ukázal, že na odborníka se obrátilo jen $15 \%$ mužů s ED a léčit se začalo pouze $61 \%$ z nich. Pouze v $19 \%$ prípadů inicioval rozhovor o ED lékař, přitom podíl mužů, kteří se

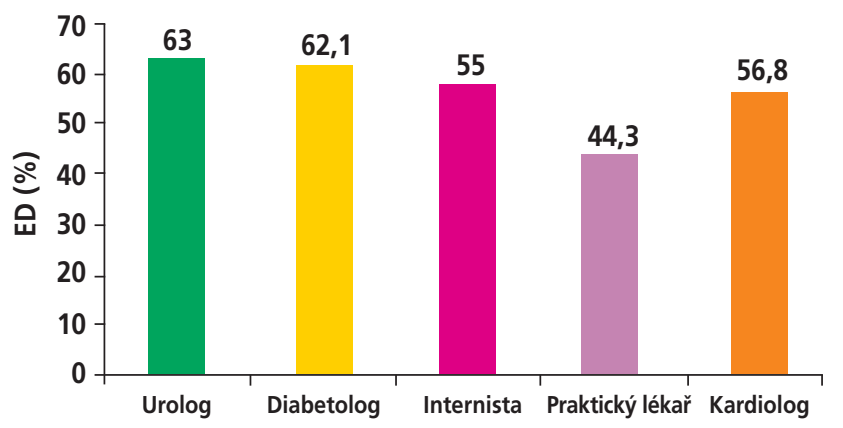

P. Weiss, J. Zvěřina, Vliv věku a somatického zdraví na erektilní funkci mužů středního věku: Výsledky reprezentativního výzkumu, Praktický lékar̆ 82 (2002) 21-23.

Obr. 1 - Podíl pacientů s těžkou a středně těžkou erektilní dysfunkcí (ED) v ambulancích českých lékařů domnívají, že by lékař na toto téma neměl mluvit, dokud se nezeptá sám pacient, činí jen necelých $14 \%$.

\section{České výzkumné projekty vnášejí nové světlo do protidestičkové léčby}

Doc. Motovská představila ve své přednášce řadu českých výzkumných prací věnovaných protidestičkové léčbě, které přinesly několik zásadních poznatků. Čeští autoři prokázali, že dávka ASA neovlivňuje laboratorní účinnost ticagreloru, jak se spekulovalo na základě amerických výsledků studie PLATO. Naše výsledky dále podporují reloading prasugrelem/ticagrelorem po podání úvodní („loading") dávky clopidogrelu u pacientů se STEMI, především u těch s „time delay" do šesti hodin. Projekty definovaly skupiny pacientů, u nichž je podávání nových inhibitorů receptorů P2Y12 pro ADP (ADPri) mandatorní: zahrnují pacienty $s$ těžkou dysfunkcí levé komory (LK), pacienty s akutním koronárním syndromem (AKS) s hemodynamickou nestabilitou a pacienty s AKS po mimonemocniční srdeční zástavě a následné kardiopulmonální resuscitaci (KPR), kteří podstupují terapeutickou hypotermii.

Evropské standardy z roku 2011 pro léčbu infarktu myokardu (IM) doporučují jako léky první volby přidané ke kyselině acetylsalicylové (ASA) nové ADPri - prasugrel a ticagrelor, $v$ prípadě jejich nedostupnosti nebo kontraindikace pak clopidogrel. Doc. Motovská se pokusila ukázat, jak jsou tato jednoznačná doporučení uplatňována v praxi. Údaje ze světových registrů ukazují nárůst pacientů léčených prasugrelem a ticagrelorem v období 2010 až 2012, což je příznivý trend, který umožní využit prínos těchto léků prokázaný v klinických studiích. Americká analýza zahrnující přes 9000 pacientů propuštěných z nemocnice s ADPri, která hodnotila výskyt komplikací spojených $s$ touto léčbou, ukázala významně častější výskyt krvácení u pacientů léčených prasugrelem nebo ticagrelorem ve srovnání s clopidogrelem, ovšem krvácení nebylo ve většině případů tak závažné, aby vedlo $k$ přerušení léčby. Celosvětové zkušenosti ukazují, že dušnost jako komplikace léčby ticagrelorem je $v$ klinické praxi násobně častější než $v$ klinické studii PLATO. $K$ přerušení léčby ticagrelorem dochází v důsledku dušnosti u 7-10 \% pacientů.

Doc. Motovská se věnovala také nevysvětlené nižší účinnosti ticagreloru v porovnání s clopidogrelem z hlediska výskytu príhod ve studii PLATO, která byla zjištěna pouze u pacientů zařazených do studie v USA. Dvě nezávislé skupiny expertů popsaly na základě statistické analýzy jako možné vysvětlení tohoto jevu vysokou udržovací 
dávku ASA ( $\geq 300$ mg), která je v USA upřednostňována. Česká studie prezentovaná na kongresu ESC v roce 2013 ovšem neprokázala souvislost mezi dávkou ASA a laboratorní účinností ADPri.

Evropské standardy doporučují podání prasugrelu u pacientů, kteří nedostali clopidogrel. Práce české skupiny, která byla prezentována v letošním roce na kongresu Americké kardiologické společnosti, ovšem ukázala, že úvodní dávka clopidogrelu 600 mg nezajištuje spolehlivou inhibici agregace trombocytů u pacientů po STEMI a perkutánní koronární intervenci $(\mathrm{PCl})$ provedenou do šesti hodin od vniku symptomů. Toto sledování podporují i výsledky předchozích studií, které ukázaly, že aktivita trombocytů je nejvyšší v prvních hodinách po IM. Toto zjištění hovoří spíše ve prospěch reloading prasugrelem/ticagrelorem u pacientů, kteři dostali iniciální dávku clopidogrelu.

Vzhledem k tomu, že dosud nebylo publikováno žádné prímé porovnání prasugrelu s ticagrelorem a doporučení vycházejí převážně ze studií TRITON a PLATO, které porovnávaly každý z těchto léků s clopidogrelem, rozhodli se čeští autoři takové porovnání provést. Do randomizované multicentrické studie PRAGUE-18, do které se zapojilo devět pracovišt' z ČR, jsou zařazováni pacienti s akutním IM indikovaní k emergentní koronarografii $\pm \mathrm{PCl}$ (do 120 minut po přijetí do kardiocentra). Pacienti jsou randomizováni $k$ léčbě prasugrelem v úvodní dávce 60 mg a udržovací dávce 10(5) mg/ den nebo ticagrelorem v úvodní dávce $180 \mathrm{mg}$ a udržovací dávce dvakrát $90 \mathrm{mg} / \mathrm{den}$.

Další tři české studie se pokusily identifikovat pacienty s AKS, kteří by měli být mandatorně léčeni novými ADPri. První práce provedená s pacienty s těžkou dysfunkcí levé komory (ejekční frakce < 35 \%) ukázala, že více než polovina těchto pacientů má vysokou reaktivitu trombocytů i při léčbě clopidogrelem. Zdá se tedy, že clopidogrel není optimálním lékem pro pacienty se závažnou systolickou dysfunkcí LK. Další práce ukázala, že účinnost clopidogrelu je nižší u pacientů s IM a závažnou hemodynamickou nestabilitou, pravděpodobně z důvodu splanchnické a jaterní hypoperfuze a podávání katecholaminů. A konečně třetí práce porovnávající účinnost prasugrelu a clopidogrelu u specifické skupiny pacientů podstupujících terapeutickou hypotermii po kardiopulmonální resuscitaci pro IM ukázala, že na rozdíl od inefektivního clopidogrelu, prasugrel účinně inhibuje agregabilitu destiček také u těchto pacientů.

\section{Volba vhodného inhibitoru receptorů pro ADP u pacientů $s$ akutním koronárním syndromem}

Terapeutické možnosti intervenčního kardiologa v př́padě $A K S$ přiblížil účastníkům kongresu MUDr. Miklík. Zahrnují arteriální prístup, mechanickou reperfuzi a farmakoterapii. Pokud se týká arteriálního prístupu, u STEMI (infarkt myokardu s elevací úseku ST) je upřednostňován radiální přístup, který snižuje výskyt krvácivých i ischemických příhod a mortalitu. Je doporučen zkušeným operatérům. Mechanická reperfuze spočívá v rozpuštění trombu, tromboaspiraci, prrípravě léze před zavedením stentu a zavedení stentu za využití vhodných zobrazovacích technik. V rámci farmakoterapie je třeba podat co nejrychleji ASA, dále antikoagulační léčbu (heparin/eno- xaparin), inhibitory Ilb/IIla (abciximab/eptifibatid i.v. i intrakoronárně) a zahájit léčbu ADPri (prasugrel, ticagrelor, clopidogrel).

Podávání ADPri vychází z již zvolené antiagregační léčby (s možností změny léčby), z typu AKS (STEMI/non-STEMI), dalších charakteristik pacienta (diabetes, renální insuficience, riziko krvácení, $C M P$, věk), ze zvolené strategie léčby (konzervativní/PCI/CABG) a z povahy intervence. Výsledky studií TRITON a PLATO ukazují větší prínos prasugrelu u STEMI v porovnání s ticagrelorem, zejména z důvodu nižšího výskytu primárního složeného parametru (mortalita, IM, CMP). U non-STEMI se jeví jako bezpečnější ticagrelor, přičemž účinnost ticagreloru a prasugrelu je srovnatelná. U ticagreloru je k dispozici více dat o předléčení clopidogrelem. Z výsledků uvedených studií také vyplývá větší snížení výskytu trombózy stentu při podávání prasugrelu (-47 \% u kovových i lékových stentů), které při podávání ticagreloru dosahuje u kovových stentů pouze $33 \%$ a u lékových stentů není statisticky významné. $U$ pacientů s $A K S$, u nichž se neprovádí $P C I$ ani CABG, nebyl prokázán přínos léčby prasugrelem oproti clopidogrelu. Vzhledem ke snížení relativního rizika mortality a primárního sledovaného parametru ve studii PLATO s ticagrelorem je u těchto pacientů výhodnější tento ADPri.

Tabulka 1 shrnuje doporučené podání jednotlivých ADPri u AKS dle platných evropských standardů. Clopidogrel je jedinou možností u pacientů s elektivní $\mathrm{PCl}$ a při AKS po předchozím intrakraniálním krvácení nebo s nutností trvalé antikoagulace, prasugrel upřednostňujeme při STEMI a při AKS u diabetiků 2. typu, ticagrelor naopak při konzervativní léčbě $A K S$ a u pacientů s renální

\begin{tabular}{|c|c|c|c|}
\hline Klinická indikace & Clopidogrel & Prasugrel & Ticagrelor \\
\hline Elektivní PCI & +++ & & \\
\hline AKS konzervativně & + & & ++ \\
\hline $\begin{array}{l}\text { non-STE AKS PCI plánována } \\
\text { - Clopidogrel preload } \\
\text { - Dosud bez clopidogrelu } \\
\text { - Urgentní CABG } \\
\text { nepravděpodobný } \\
\text { (nízké riziko) } \\
\text { - Urgentní CABG } \\
\text { pravděpodobný } \\
\text { (vysoké riziko) }\end{array}$ & $\begin{array}{l}+ \\
+ \\
+ \\
+\end{array}$ & $\begin{array}{l}++ \\
++ \\
++\end{array}$ & $\begin{array}{l}++ \\
++ \\
++ \\
++\end{array}$ \\
\hline $\begin{array}{l}\text { STE AKS (včetně } \\
\text { trombózy stentu) }\end{array}$ & + & +++ & ++ \\
\hline $\mathrm{AKS}+\mathrm{CHRI}$ & + & + & ++ \\
\hline AKS + diabetes mellitus & + & +++ & ++ \\
\hline $\begin{array}{l}\text { AKS + předchozí } \\
\text { ischemická CMP/TIA }\end{array}$ & + & & ++ \\
\hline $\begin{array}{l}\text { AKS + předchozí } \\
\text { intrakraniální krvácení }\end{array}$ & +++ & & \\
\hline $\begin{array}{l}\text { AKS + nutnost trvalé } \\
\text { antikoagulace }\end{array}$ & +++ & & \\
\hline
\end{tabular}

+ může být podán, ++ doporučeno, +++ důrazně doporučeno/ jediná možnost.

Upraveno dle ESC a guidelines pro léčbu STEMI 2012 a non-STE AKS 2011. 
insuficiencí či předchozí ischemickou cévní mozkovou příhodou. U non-STEMI je stejně výhodné použití prasugrelu i ticagreloru s výjimkou pacientů s pravděpodobností urgentního CABG a předchozí úvodní dávkou clopidogrelu, kde upřednostňujeme ticagrelor.

Podle úhradové vyhlášky platné od 1. prosince 2013 je preskripce clopidogrelu uvolněna pro praktické lékaře. Tento lék je plně hrazený pojištovnou při alergii/rezistenci na ASA, u intravaskulární intervence s vysokým rizikem, při zavedení kovového stentu (po dobu jednoho měsíce), při zavedení lékového stentu (po dobu devíti měsíců) a u non-STEMI (po dobu 12 měsíců). Při léčbě AKS je po dobu 12 měsíců doplatek na prasugrel 1430 Kč/měsíc, na ticagrelor $2044 \mathrm{Kč/měsíc.} \mathrm{Existuje} \mathrm{ovšem} \mathrm{možnost} \mathrm{zvýše-}$ né úhrady těchto přípravků ze strany pojištovny, kdy činí doplatek pouze $98 \mathrm{Kč/měsíc} \mathrm{u} \mathrm{prasugrelu} \mathrm{a} 120 \mathrm{Kč} / \mathrm{měsíc}$ u ticagreloru až po dobu 12 měsíců. Tato zvýšená úhrada se týká prasugrelu u pacientů se STEMI s kritickou lokalizací implantovaného stentu (kmen levé koronární tepny, bifurkace, difuze) nebo se suboptimální apozicí stentu (nepř́iznivá anatomická situace, kalcifikace) a se STEMI při akutní trombóze stentu při terapii clopidogrelem, léčbu zahajuje intervenční kardiolog. V ČR je za rok asi 1000 pacientů s indikací zvýšené úhrady prasugrelu. Ticagrelor je ze strany pojištovny hrazen ve zvýšené míře u pacientů $s$ AKS léčených CABG do sedmi dnů od přerušení léčby, léčbu zahajuje kardiochirurg.

MUDr. Miklík uzavřel svoji přednášku objasněním postupu léčby prasugrelem u pacientů se STEMI. Intervenční kardiolog po provedení intervence zhodnotí rizikovost léze a doporučí terapii prasugrelem na 12 měsíců. Dle nálezu je možné indikovat zvýšenou úhradu prasugrelu ze strany pojištovny. Akutní kardiolog potvrdí indikaci prasugrelu a po rozhovoru s pacientem tento lék předepíše. Ambulantní kardiolog poté kontroluje compliance s léčbou prasugrelem při dávkování jednou denně ráno, a to po dobu 12 měsíců.

MUDr. Zuzana Zafarová

Článek je podpořen společností Eli Lilly; CZEFF00096 